\title{
Synovial biopsies in clinical practice and research: current developments and perspectives
}

\author{
Hanna Johnsson ${ }^{1}$ (D) Aurélie Najm ${ }^{1}$ (D) \\ Received: 26 July 2020 / Revised: 31 October 2020 / Accepted: 15 November 2020 / Published online: 4 December 2020 \\ (C) The Author(s) 2020
}

\begin{abstract}
Synovial biopsy techniques have developed and widely expanded over the past few years, in particular due to the development of ultrasound-guided procedures. This article reviews the different techniques, clinical applications, and the latest advances in translational research as well as current challenges and perspectives. The first part focuses on different techniques available for biopsy, along with their feasibility, success rate, tolerance, and training requirements. In the second part, clinical applications are described. Data on diagnostic performances are reported, especially regarding septic arthritis. Translational research applications are described and explained in the final part, from the early histological studies and the first description of pathotype to more recent technologies involving -omics. Latest developments involving single-cell RNA sequence analysis have allowed the discovery of new cell subpopulations with remarkable roles in RA pathophysiology. These studies pave the ground for the discovery of new therapeutic targets and the implementation of personalized therapy in RA.
\end{abstract}

Key Point

-This review provides an overview of synovial biopsy techinques and applications especially in clinical and translational research.

Keywords Arthritis · Biopsy $\cdot$ Synovial biopsy $\cdot$ Synovitis $\cdot$ Synovium $\cdot$ Ultrasound

\section{Different biopsy techniques}

\section{Brief history and introduction of techniques}

Arthroscopic synovial biopsy has traditionally been considered the gold standard for obtaining synovial tissue. It enables the operator to view the synovium macroscopically and choose where to take the biopsy [1]. The macroscopic inspection can also yield diagnostic information [2]. With the invention of thinner arthroscopes, the procedure became less invasive, and more rheumatologists performed arthroscopic biopsies throughout the 1990s [3].

However, arthroscopic synovial biopsies are invasive, expensive, and not widely available. Alongside the practice of

Aurélie Najm

aurelie.najm@gmail.com

1 Institute of Infection, Immunity and Inflammation, College of Medical Veterinary and Life Sciences, University of Glasgow and Rheumatology Department Greater Glasgow and Clyde,

Glasgow, UK arthroscopic synovial biopsy procedures, less invasive, simpler, and cheaper techniques for obtaining synovial biopsies were developed. Early blind biopsy needles measured $5 \mathrm{~mm}$ across so remained invasive [4]. Subsequent blind biopsy needles, like the Parker and Pearson needle, were thinner (14G, 15G, and 18G) and widely used [5, 6]. Samples obtained from the suprapatellar pouch by blind needle biopsies show broadly similar features to samples taken using arthroscopy $[4,7]$, but sufficient tissue for histological analysis is only obtained in 61 to $85 \%$ of cases $[8,9]$. The procedure is also limited to larger joints.

To improve success rates and ensure that biopsies are taken from the synovium, imaging-guided biopsy techniques evolved. Imaging modalities reported include fluoroscopy and CT scanning $[10,11]$, but ultrasound (US) has become the preferred method to visualize the joint. US is free of ionizing radiation, and many rheumatologists use US in their daily clinical practice.

Since first reported in 1997 [12], US-guided synovial biopsies (US-SB) are now routinely performed in many centres throughout the world. An advantage of US-SB over 
Fig. 1 a and $\mathbf{b}$ Ultrasound guided synovial biopsy. a Procedure with the semi-automatic guillotine needle. $\mathbf{b}$ US image of a shoulder synovitis and the biopsy needle. $\mathbf{c}$ and $\mathbf{d}$ Synovial tissue from an inflamed knee joint in RA. c Haematoxylin and Eosin staining. d CD68+ macrophages staining

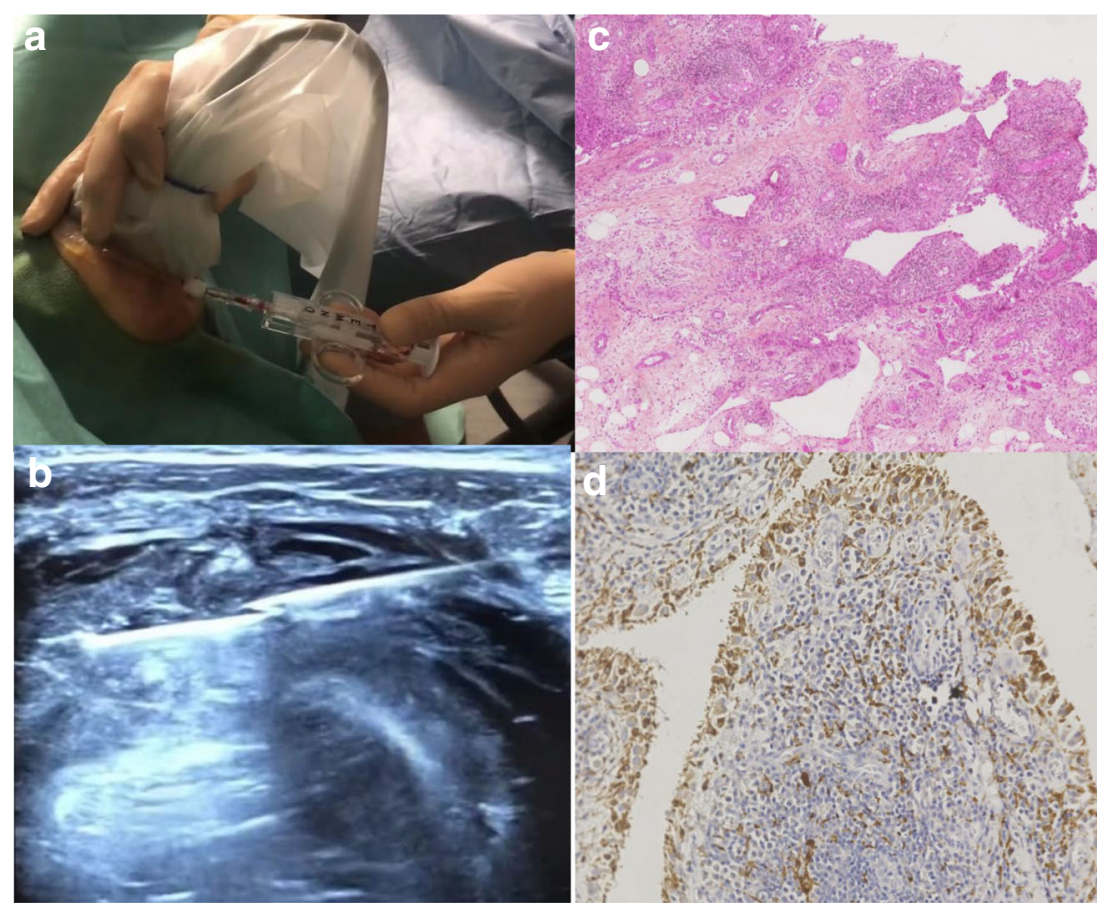

arthroscopic and blind biopsies is that they can safely and successfully be performed on both large and small joints [13-15]. The most frequently biopsied joints are wrists, knees, MCPs, and ankles, but also elbows, shoulders, hips, sternoclavicular, acromioclavicular, and pubic symphysis biopsies are performed $[13,15,16]$. Figure 1 shows photos of an US-SB being performed, and the microscopic appearances of the tissue obtained.

\section{What is involved for the patient?}

Arthroscopic synovial biopsies are typically performed in an operating theatre or in a procedure room [3]. Most are performed using local anaesthetic, but general anaesthetic is used in more than 1 in 5 procedures [16]. Half of the centres always or often prescribe sedation [3]. Two ports are required: one for the arthroscope and one for the biopsy forceps. The diameter of the arthroscope is between 1.9 and $4.5 \mathrm{~mm}$ [6]. The operator can inspect the macroscopic appearance of the joint and choose the biopsy site. Adequate samples can be obtained also after inflammation has been successfully treated [6]. Joint lavage with saline can be performed, and this can be therapeutic [1]. The port sites are usually closed with steristrips, though sutures are sometimes used [3]. No specific observation is required for most procedures.
US-SB require less specialist equipment than arthroscopic biopsies. They can be obtained using portal and biopsy forceps or a semi-automated core biopsy needle. In both cases, local anaesthetic is infiltrated into the skin, soft tissues, and synovial space. For portal and forceps, the portal is inserted into the synovial space under US guidance and biopsy forceps introduced through the portal. Semi-automated core biopsy needles can either be introduced repeatedly through the same tract under US guidance or through an introducer which acts as a portal. US grey scale and power Doppler signal guide the operator to the site of the highest inflammation. Multiple synovial biopsies are taken, ideally from different parts of the joint. As the puncture site usually is no larger than $2 \mathrm{~mm}$, steri strips are sufficient to close the wound. The procedure typically takes less than $1 \mathrm{~h}$ to perform, and patients can leave soon thereafter. Patients are advised to rest the biopsied joint for $48 \mathrm{~h}$ after the procedure.

\section{Patient acceptance and tolerability}

Minimally invasive synovial biopsy procedures are well-tolerated. A comparison of 402 US-guided needle biopsies, 65 US-guided portal and forceps biopsies, and 57 arthroscopicguided synovial biopsies did not identify any difference in the post-biopsy pain, swelling, or stiffness between the three procedures [16]. Pain, swelling, and stiffness are unchanged or 
reduced following biopsy compared to before the procedure [16-18]. Steroids reduce post-procedure swelling significantly but do not improve pain or stiffness significantly [16]. The discomfort during the procedure is higher for large joints than small- and medium-sized joints [17].

The majority of patients is somewhat or very likely to agree to another biopsy, with patient undergoing US-guided needle biopsies less willing than those undergoing US-guided portal and forceps biopsies or arthroscopic biopsies [16-18]. The willingness does not decline after a second biopsy [16].

\section{Complications}

The complication rates of minimally invasive arthroscopic and US-SB are similar between studies and summarized in Table 1 .

Based on a survey of 15682 procedures, the most common complications of arthroscopic synovial biopsies performed by rheumatologists are haemarthosis in $0.9 \%$ and DVT in $0.2 \%$ of patients. Joint infection, wound infection, and neurological damage occur in $0.1 \%, 0.1 \%$, and $0.02 \%$, respectively [3].

Studies on the complication rates of US-SB are smaller, and many do not report any major complications. The largest study to date included 402 US-guided needle biopsies and 65 US-guided portal and forceps biopsies and identified a complication rate of $8 / 467(1.71 \%)$ [16]. These comprised of 2 episodes of syncope or presyncope, 1 tenosynovitis, 4 sensory impairment, and 1 haemarthrosis. Syncope or presyncope have been reported by others as between 0.8 and $3.2 \%$ [16, 17, 19]. Motor neurological complications, both transient paresis due to local anaesthesia and persistent mild limitation of digit extension, have occurred following wrist biopsies [18]. Minor bleeding occurs in up to $7.8 \%$ of procedures [18], but haemarthrosis is rare with rates up to $1.3 \%$ in individual studies [15]. Skin infection was reported in one study [14].

The most common minor complications following US-SB are mild arthralgia and increased use of analgesia following the procedure, occurring following $19.4 \%$ and $36 \%$ procedures, respectively $[17,18]$. There is no increase in adverse event in patients on biologic treatments [17].

\section{Success of procedure}

The definition of success varies between studies historically. Current recommendations stipulate that the synovial lining layer should be present and that an area of $2.5 \mathrm{~mm}^{2}$ is required for representative staining [22]. Due to tissue heterogeneity, it is recommended that at least four biopsies are taken from small joints and six biopsies from large joints [22]. The yield of tissue depends on US grey scale synovitis with the highest yield with synovial grade 3 [17]. There is a trend for more successful samples from large joints than small joints.

Of 7 studies included in a systematic review, only three clearly defined success as an intact lining layer [13]. The success rate in these three studies was $89-100 \%$. A somewhat lower success rate of US-SB was reported in an observational study in which 62 of 76 clinical procedures $(81.6 \%)$ yielded synovial tissues [15]. Synovial lining was seen in $92.6 \%$ of successful procedures. The failed biopsies occurred in both small and large joints, and the authors comment that inexperience contributed to biopsy failure. The proportion of gradable synovial tissue is lower when blind needle biopsies are used compared to US-guided and arthroscopic procedures [9]. For large joints, US-SB perform as well as arthroscopic biopsies.

\section{Training}

Arthoscopic biopsies require considerable training. Observation of 5 procedures, assisting at 10 procedures and performing 10 procedures supervised, has been proposed as adequate training before independence [3]. More recently, the European League Against Rheumatism (EULAR) has been working towards the creation of a EULAR standardized

Table 1 Success rate, complications, and tolerability of arthroscopic and US-guided synovial biopsies [1, 3, 13-21]

\begin{tabular}{|c|c|c|c|}
\hline & Arthroscopic & US-guided biopsy semi-automatic needle & $\begin{array}{l}\text { US-guided biopsy portal } \\
\text { and forceps }\end{array}$ \\
\hline Success rate & $>90 \%$ & $\begin{array}{l}\text { Around } 80-90 \% \text { depends on } \\
\text { US grey scale } \\
\text { synovitis grade, joint size, and } \\
\text { operator experience }\end{array}$ & Around $80-90 \%$ \\
\hline Complications & $\begin{array}{l}1.51 \% \text { complication rate, haemarthrosis } 0.9 \% \text {, } \\
\text { DVT } 0.2 \% \text {, wound infection } 0.1 \% \text {, joint } \\
\text { infection } 160.1 \% \text {, thrombophlebitis } 0.08 \% \text {, } \\
\text { flare of gout } 0.06 \% \text {, syncope/vasovagal } 0.02 \% \text {, } \\
\text { neurological } 0.02 \%\end{array}$ & $\begin{array}{l}\text { Minor bleeding up to } 7.8 \% \text {, } \\
\text { haemarthrosis } 0.3-1.3 \% \text {, } \\
\text { neurological up to } 3.1 \% \text {, vasovagal } \\
\text { symptoms } 0.8 \\
\text { to } 3.2 \% \text {, rare: tenosynovitis }\end{array}$ & $\begin{array}{l}\text { Skin infection ( } 1 \text { of } 37 \\
\text { procedures in one study) }\end{array}$ \\
\hline Tolerability & $62 \%$ no or mild discomfort & $70-92.8 \%$ no or mild discomfort & $71 \%$ no or mild discomfort \\
\hline $\begin{array}{l}\text { Willingness of repeat } \\
\text { biopsy }\end{array}$ & $64 \%$ likely or somewhat likely & $57-74 \%$ likely or somewhat likely & $\begin{array}{l}85 \% \text { likely or somewhat } \\
\text { likely }\end{array}$ \\
\hline
\end{tabular}

Fewer studies have reported on US-guided port-and-forceps biopsies than arthroscopic and US-guided needle biopsies 
training model for ultrasound-guided synovial biopsy procedures in large and small joints leading to an educational video and recommendations (Moller et al., ongoing).

\section{Clinical utility}

\section{Synovial biopsy to exclude infection}

The most common clinical indication for synovial biopsies is to rule out septic arthritis $[15,20]$. In a study reporting on 76 USguided procedures performed with clinical indications, $82.4 \%$ was performed to rule out septic arthritis [15]. Most patients had an undifferentiated chronic monoarthritis $(54.1 \%)$ or an acute monoarthritis (24\%), but cases of chronic undifferentiated oligoarthritis, chronic polyarthritis, chronic bursitis, chronic tenosynovitis, and acute polyarthritis were also biopsied. Two cases of infectious arthritis were identified, namely Lyme's disease and articular Whipple disease [15]. In the case of Whipple disease, the synovial fluid PCR had been negative. No other case of infectious arthritis was identified during follow-up, suggesting that synovial biopsy is reliable in excluding septic arthritis. The reliability of synovial biopsies to exclude infection in native joints has been replicated by others $[18,19]$.

A causative organism is identified in less than half of patients who clinically have septic arthritis, and a synovial biopsy can be informative [20,23]. In a study where $90 \%$ of participants had a synovial fluid aspirate and $25 \%$ had a synovial biopsy taken, the causative organism was grown in $38.7 \%$ of synovial fluid samples and $23.5 \%$ of synovial membranes. Antibiotics had not been given prior to synovial fluid aspirate but could have been given before the synovial biopsy. Nonetheless, in three cases (one mycobacterium and two Staphylococcus aureus), the synovial tissue was positive on culture, but the synovial fluid was negative [20, 23]. Moreover, bacterial DNA is detectable in synovial tissue for longer than gram stain and positive cultures and can be detected after empirical antibiotics have been started [24]. A high synovial neutrophil (CD15+) count (absolute and relative) is also supportive of a diagnosis of septic arthritis [20,25]. When synovial biopsies are performed in patients with suspected infectious arthritis, qPCR analysis for 16S RNA, Borrelia Burgdorferi and Tropheryma Whipplei are recommended [22].

\section{Diagnoses made with synovial biopsies}

In most cases, synovial biopsies taken with clinical indications do not yield a specific diagnosis $[15,18]$. Nonetheless, a number of specific diagnosis have been reported, including gout and pseudogout with deposits found within the synovial tissue, even when synovial fluid analysis is negative $[6,15,18]$. Importantly, the synovial tissue needs to be preserved in absolute ethanol rather than formalin to prevent urate crystals from dissolving.
Other pathologies which can be identified on synovial biopsy include amyloidosis with deposits which stain red with Congo red stain and synovial chondromatosis with cartilage nodules seen within the synovial tissue $[18,26]$. In ochronosis, haemachromatosis, and recurrent haemarthrosis, specific pigments are seen. A brown colour from macrophages carrying haemosiderin is also seen in pigmented villonodular synovitis along with hypercellularity in the sublining layer. There are rare synovial malignancies including synovial chondrosarcoma, synovial haemangiomas, lipoma aborescens, and intracapsular chondromas [26]. The pathological diagnosis of tumours identified by synovial biopsies is compatible with pathological diagnosis from synovectomy samples [19]. Also lymphoprolipherative disorders can present within the synovium, and sarcoidosis, foreign body arthritis, the histiocytic disorder Erdheim-Chester disease and multicentric reticulohistocytosis have been diagnosed with synovial biopsies [15, 18, 19, 27].

\section{Utility in inflammatory arthritis}

In cases lacking clear distinguishing pathological features, synovial biopsies can still support a diagnosis of inflammatory arthritis. The Krenn score gives a score between 0 and 3 to the histological features of enlargement of synovial lining cell layer, density of resident cells, and inflammatory infiltrate. It defines synovitis histologically as low-grade (2-4) and highgrade (5-9) synovitis [28]. Using the cut-off of 4, inflammatory arthritis can be differentiated from healthy controls and degenerative disease with a specificity of $96.1 \%$ and sensitivity of $61.7 \%$ [28]. By adding immunostaining with CD68, CD3, CD20, CD31, and Ki67, the specificity and sensitivity for differentiating inflammatory arthritis from osteoarthritis are improved [29].

To date, there is no validated histological score which can differentiate between different types of inflammatory arthritis in individual patients. On a disease level, however, there are differences. Patients with spondyloarthritis (SpA) have increased vasculature with tortuous vessels, and this is seen both macroscopically and microscopically $[1,30]$. The cellular infiltrate in the synovium is different depending on the presence of a joint effusion in RA and SpA [30]. Patients with RA with joint effusions have increased $B$ cell and $T$ cell staining compared to patients with $\mathrm{SpA}$ with joint effusions. Furthermore, patients with early RA have increased staining of plasma cells, B cells, and macrophages compared to non-RA early arthritis [31]. Minimal staining of plasma cells and macrophages predicts a diagnosis other than RA in $96 \%$ cases [31]. In addition, specific synovial signatures including the expression of chemokines ((C-X-C motif) ligand 4 (CXCL4) and CXCL7), and fibroblast activation protein (FAP) differentiate early RA from other inflammatory arthritis of recent onset [32, 33]. 


\section{Translational research}

With the wider availability of US-SB, the procedure is increasingly used to obtain tissue for research. Thus, the analysis of synovial tissue has been used over the past few decades in translational research to increase our knowledge and understanding of the pathophysiology of rheumatic diseases, to predict treatment response, and to help discover new therapeutic targets.

Given the sensitivity to change of the tissue, especially in terms of cell infiltrate, synovitis histological assessment is considered a reliable biomarker of response to treatment [34].

\section{Histological stratification}

Histological analysis, by permitting the analysis of tissue cell infiltrates in RA synovium, allows for better stratification of RA patients across disease states and phenotypes. This has led to the concept of synovial pathotypes which was first introduced by Dennis et al. [35]. Pathotypes are defined by a specific cell type enrichment within the synovial tissue and are associated with a well-defined underlying molecular signature [35]. Four different pathotypes were initially described: lymphoid enriched in B and T cells, myeloid enriched in macrophages, fibroid, and pauci-immune [35]. The concept of pathotypes was further developed by others as lympho-myeloid, diffuse-myeloid, and pauci-immune, and these three patterns are present also in early RA [21,36].

Numerous studies have assessed the relationship between pathotypes and RA disease phenotypes. The lymphoid pathotype is associated with the presence of ectopic lymphoid follicles. Their presence in the synovial tissue has been inconsistently reported as associated with disease activity and an erosive RA phenotype [21, 37-40]. The pauci-immune phenotype is associated with lower levels of CRP [21, 41].

This being said, cell populations within the synovial membrane infiltrate are highly heterogeneous, and are influenced by many different parameters, such as disease duration [42], ACPA status in RA [43, 44], disease activity [45], and biological treatment. Therefore, studies focusing on gene expression signatures in addition to, or instead of, the histological cell composition have been developed in order to provide a more accurate patient stratification and personalized therapies approaches.

\section{Towards personalized therapy using molecular signatures}

The histological pathotypes are associated with well-defined molecular signatures $[21,35,46]$. The inclusion of this information in prediction models can improve the sensitivity and specificity of patients' classification in comparison to 1987 ACR criteria [47] in a cohort of 200 early arthritis patients, including RA and undifferentiated arthritis patients [46]. Myeloid- and lymphoid-associated genes correlate to disease activity and response to treatment at 6 months, while a lymphoid molecular signature correlates to an osteoclasts-related gene enrichment and predicted structural damages progression at 12 months [21].

Although histologically defined pathotypes are not associated with csDMARD response in early RA, related molecular signatures are associated with response to csDMARDs [21]. Furthermore, the lympho-myeloid pathotype, with enriched inflammatory gene expression including IL- 6 and TNF $\alpha$, is associated with a higher prescription of biological DMARDs [46].

Pathotypes and molecular signatures have also been used to predict response to biological treatments. For example, patients with the myeloid phenotype are better responders to TNF blockade [35], and transcripts associated with lymphoid pathotype predict a good response to infliximab therapy [48]. Enrichment of B cells in cellular infiltrates and B cell linage transcripts on the other hand are associated with a poor response to TNF inhibitors [49], as is the pauci-immune phenotype [41].

Of interest, Badot et al. performed gene expression studies along with immunohistochemistry without consideration of pathotypes [50]. They demonstrated that high baseline synovial expression of interleukin-7 receptor alpha chain (IL-7R), CXCL11, IL-18, IL-18 receptor accessory (IL-18rap), and MKI67 predicts a poor response to adalimumab therapy [50].

These studies show promise for personalized medicine in RA, and further studies are ongoing. Alongside, new singlecell and -omics technologies are rapidly improving our understanding of disease pathophysiology and may enable the identification of new therapeutic targets.

\section{New single-cell technologies}

New distinct cell subpopulations have been identified in RA using technologies linking transcriptomics and proteomics through single-cell RNA seq, mass spectrometry, bulk RNA seq, and flow cytometry. The Accelerating Medicines Partnership Rheumatoid Arthritis and Lupus (AMP RA/ SLE) consortium mapped cell subpopulations according to their production of cytokines [51]. Indeed, new T cell populations, such as $\mathrm{PDCD}^{+} \mathrm{T}$ peripheral helper and $\mathrm{T}$ follicular helper $\mathrm{T}$ cells, were newly described, and a pro-inflammatory subpopulation of sublining fibroblasts, THY1(CD90) ${ }^{+}$HLADRA $^{\text {hi }}$, is the main producer of IL- 6 . The pathogenic role of resident synovial fibroblasts was also emphasized in recent work from Croft et al., who described novel fibroblast subpopulations within RA synovial tissue using single-cell RNA sequencing [52]. Two populations with distinct roles were described: the fibroblast activation protein- $\alpha$ (FAP $\alpha)$ - positive thymus cell antigen 1 (THY1) positive synovial fibroblasts (FAP $\alpha+\mathrm{THY} 1+)$ located in the synovial sublining and able to regulate inflammation through cytokines and chemokines secretion, and the FAP $\alpha+$ THY1-fibroblasts 
located in the lining layer responsible for bone and cartilage destruction and an invasive phenotype.

More recently, Alivernini et al. studied macrophage subpopulations across disease states in RA, using synovial tissue from active RA and remission [53]. They identified two new subpopulations of synovial tissue macrophages (MerTK ${ }^{\text {pos }}{ }^{2 D 206}{ }^{\text {pos }}$ and MerTK ${ }^{\text {pos }} \mathrm{LYVE1}^{\text {pos }}$ ) displaying transcriptomic signatures enriched in negative regulators of inflammation. The presence of these populations was associated with remission maintenance, suggesting a promising potential therapeutic role of these cells in RA.

Although most work has focused on RA, Wade et al. identified a polyfunctional T cell subset in PsA using flow cytometry of digested PsA synovial tissue [54]. These CD4 + CD161+ T cells produce high concentrations of pro-inflammatory cytokines, including IL-17A, IFN $\gamma$, and TNF. Their presence correlates highly to PsA disease activity expressed by the disease activity in psoriatic arthritis (DAPSA).

Further agenda in the field of synovial tissue research includes projects related to education, clinical applications, translational research, quality appraisal of research, and therapy. The research agenda is detailed in Table 2.

In conclusion, RA and other rheumatic diseases are characterized by synovial inflammation, and the retrieval and analysis of synovial biopsies have improved the understanding of disease pathophysiology. Minimally invasive US-SB techniques are safe, well-tolerated, and widely performed. In addition to a demonstrated utility in different clinical situations, synovial tissue analysis, at a cellular and molecular level initially and a molecular lever more recently, has driven important developments in rheumatology. The implementation and use of cutting-edge technologies in translational research are currently allowing new insights and identification of new cell

Table 2 Research agenda

Education
O Establishment of consensual training requirements
○ Development of a training framework and practical opportunities
Clinical applications
o Development and implementation of synovial tissue biomarkers for
diagnosis or prognosis for RMDs in clinical practice
Translational research
O Synovial tissue atlas (multi-omics approach) in RMDs
O Assessment of tissular miRNA signature through single-cell ap-
proaches (single-cell miRNome) in RMDs
Quality appraisal of research
O EULAR points to consider for minimal reporting requirements in
synovial tissue clinical practice and research in rheumatology
Therapy
O Personalized medicine and sequential therapy in RMDs
O Synovial cells reprogramming

subsets involved in different states of rheumatic diseases. Such data will allow a better understanding of disease phenotypes, predict treatment response, and constitute a rationale for the development of new cell-targeted therapies.

Authors' contributions $\mathrm{HJ}$ and $\mathrm{AN}$ contributed to literature review, writing, and reviewing the manuscript.

Data Availability Not applicable

\section{Compliance with ethical standards}

Conflict of interest The authors declare that they have no conflict of interest.

Ethics approval Not applicable

Consent to participate Not applicable

Consent for publication Not applicable

Code availability Not applicable

Open Access This article is licensed under a Creative Commons Attribution 4.0 International License, which permits use, sharing, adaptation, distribution and reproduction in any medium or format, as long as you give appropriate credit to the original author(s) and the source, provide a link to the Creative Commons licence, and indicate if changes were made. The images or other third party material in this article are included in the article's Creative Commons licence, unless indicated otherwise in a credit line to the material. If material is not included in the article's Creative Commons licence and your intended use is not permitted by statutory regulation or exceeds the permitted use, you will need to obtain permission directly from the copyright holder. To view a copy of this licence, visit http://creativecommons.org/licenses/by/4.0/.

\section{References}

1. Baeten D, Van den Bosch F, Elewaut D, Stuer A, Veys EM, De Keyser F (1999) Needle arthroscopy of the knee with synovial biopsy sampling: technical experience in 150 patients. Clin Rheumatol 18(6): 434 -441. https://doi.org/10.1007/s100670050134

2. Altman RD, Gray R (1983) Diagnostic and therapeutic uses of the arthroscope in rheumatoid arthritis and osteoarthritis. Am J Med 75(4B):50-55. https://doi.org/10.1016/0002-9343(83)90328-5

3. Kane D, Veale DJ, FitzGerald O, Reece R (2002) Survey of arthroscopy performed by rheumatologists. Rheumatology (Oxford) 41(2):210-215. https://doi.org/10.1093/rheumatology/41.2.210

4. Polley HF, Bickel WH (1951) Punch biopsy of synovial membrane. Ann Rheum Dis 10(3):277-287. https://doi.org/10.1136/ard.10.3.277

5. Parker RH, Pearson CM (1963) A simplified synovial biopsy needle. Arthritis Rheum 6:172-176. https://doi.org/10.1002/art.1780060209

6. Gerlag DM, Tak PP (2013) How to perform and analyse synovial biopsies. Best Pract Res Clin Rheumatol 27(2):195-207. https:// doi.org/10.1016/j.berh.2013.03.006

7. Youssef PP, Kraan M, Breedveld F, Bresnihan B, Cassidy N, Cunnane G, Emery P, Fitzgerald O, Kane D, Lindblad S, Reece R, Veale D, Tak PP (1998) Quantitative microscopic analysis of inflammation in rheumatoid arthritis synovial membrane samples 
selected at arthroscopy compared with samples obtained blindly by needle biopsy. Arthritis Rheum 41 (4):663-669. 10.1002/15290131(199804)41:4 < 663::AID-ART13 > 3.0.CO;2-L

8. Gerlag D, Tak PP (2005) Synovial biopsy. Best Pract Res Clin Rheumatol 19(3):387-400. https://doi.org/10.1016/j.berh.2005.01.005

9. Humby F, Romao VC, Manzo A, Filer A, Bugatti S, Vieira-Sousa E, Kelly S, Wechalekar M, Ahmed M, Rocher V, Hands R, Montecucco C, Fonseca J, Pitzalis C (2018) A multicenter retrospective analysis evaluating performance of synovial biopsy techniques in patients with inflammatory arthritis: arthroscopic versus ultrasound-guided versus blind needle biopsy. Arthritis Rheumatol 70(5):702-710. https://doi.org/10.1002/art.40433

10. Beaule V, Laredo JD, Cywiner C, Bard M, Tubiana JM (1990) Synovial membrane: percutaneous biopsy. Radiology 177(2): 581-585. https://doi.org/10.1148/radiology.177.2.2217803

11. McKee TC, Belair JA, Sobol K, Brown SA, Abraham J, Morrison W (2020) Efficacy of image-guided synovial biopsy. Skeletal Radiol 49(6):921-928. https://doi.org/10.1007/s00256-019-03370-2

12. van Vugt RM, van Dalen A, Bijlsma JW (1997) Ultrasound guided synovial biopsy of the wrist. Scand J Rheumatol 26(3):212-214. https://doi.org/10.3109/03009749709065683

13. Lazarou I, D'Agostino MA, Naredo E, Humby F, Filer A, Kelly SG (2015) Ultrasound-guided synovial biopsy: a systematic review according to the OMERACT filter and recommendations for minimal reporting standards in clinical studies. Rheumatology (Oxford) 54(10):1867-1875. https://doi.org/10.1093/rheumatology/kev128

14. Koski JM, Helle M (2005) Ultrasound guided synovial biopsy using portal and forceps. Ann Rheum Dis 64(6):926-929. https:// doi.org/10.1136/ard.2004.027409

15. Najm A, Orr C, Heymann MF, Bart G, Veale DJ, Le Goff B (2016) Success rate and utility of ultrasound-guided synovial biopsies in clinical practice. J Rheumatol 43(12):2113-2119. https://doi.org/ $10.3899 /$ jrheum. 151441

16. Just SA, Humby F, Lindegaard H, Meric de Bellefon L, Durez P, Vieira-Sousa E, Teixeira R, Stoenoiu M, Werlinrud J, Rosmark S, Larsen PV, Pratt A, Choy E, Gendi N, Buch MH, Edwards CJ, Taylor PC, McInnes IB, Fonseca JE, Pitzalis C, Filer A (2018) Patient-reported outcomes and safety in patients undergoing synovial biopsy: comparison of ultrasound-guided needle biopsy, ultrasound-guided portal and forceps and arthroscopic-guided synovial biopsy techniques in five centres across Europe. RMD Open 4(2):e000799. https://doi.org/10.1136/rmdopen-2018-000799

17. Kelly S, Humby F, Filer A, Ng N, Di Cicco M, Hands RE, Rocher V, Bombardieri M, D'Agostino MA, McInnes IB, Buckley CD, Taylor PC, Pitzalis C (2015) Ultrasound-guided synovial biopsy: a safe, well-tolerated and reliable technique for obtaining highquality synovial tissue from both large and small joints in early arthritis patients. Ann Rheum Dis 74(3):611-617. https://doi.org/ 10.1136/annrheumdis-2013-204603

18. Romao VC, Polido-Pereira J, Barros R, Luis R, Vidal B, VieiraSousa E, Vitorino E, Humby F, Kelly S, Pitzalis C, Saraiva F, Fonseca JE (2019) Efficacy, safety and sample quality of ultrasound-guided synovial needle biopsy in clinical practice and research: a prospective observational study. Arthritis Care Res (Hoboken). 72:1497-1505. https://doi.org/10.1002/acr.24050

19. Sitt JC, Griffith JF, Lai FM, Hui M, Chiu KH, Lee RK, Ng AW, Leung J (2017) Ultrasound-guided synovial Tru-cut biopsy: indications, technique, and outcome in 111 cases. Eur Radiol 27(5):20022010. https://doi.org/10.1007/s00330-016-4545-6

20. Coiffier G, Ferreyra M, Albert JD, Stock N, Jolivet-Gougeon A, Perdriger A, Guggenbuhl P (2018) Ultrasound-guided synovial biopsy improves diagnosis of septic arthritis in acute arthritis without enough analyzable synovial fluid: a retrospective analysis of 176 arthritis from a French rheumatology department. Clin Rheumatol 37(8):2241-2249. https://doi.org/10.1007/s10067-018-4160-9
21. Humby F, Lewis M, Ramamoorthi N, Hackney JA, Barnes MR, Bombardieri M, Setiadi AF, Kelly S, Bene F, DiCicco M, Riahi S, Rocher V, Ng N, Lazarou I, Hands R, van der Heijde D, Landewe RBM, van der Helm-van Mil A, Cauli A, McInnes I, Buckley CD, Choy EH, Taylor PC, Townsend MJ, Pitzalis C (2019) Synovial cellular and molecular signatures stratify clinical response to csDMARD therapy and predict radiographic progression in early rheumatoid arthritis patients. Ann Rheum Dis 78(6):761-772. https://doi.org/10.1136/annrheumdis-2018-214539

22. Najm A, Le Goff B, Orr C, Thurlings R, Canete JD, Humby F, Alivernini S, Manzo A, Just SA, Romao VC, Krenn V, MullerLadner U, Addimanda O, Tas SW, Stoenoiu M, Meric de Bellefon L, Durez P, Strand V, Wechalekar MD, Fonseca JE, Lauwerys B, Fearon U, Veale DJ, Group ESS, Group OSTSI (2018) Standardisation of synovial biopsy analyses in rheumatic diseases: a consensus of the EULAR Synovitis and OMERACT Synovial Tissue Biopsy Groups. Arthritis Res Ther 20(1):265. https://doi.org/10.1186/s13075-018-1762-1

23. Madruga Dias J, Costa MM, Pereira da Silva JA, Viana de Queiroz M (2014) Septic arthritis: patients with or without isolated infectious agents have similar characteristics. Infection 42(2):385-391. https://doi.org/10.1007/s15010-013-0567-z

24. van der Heijden IM, Wilbrink B, Vije AE, Schouls LM, Breedveld FC, Tak PP (1999) Detection of bacterial DNA in serial synovial samples obtained during antibiotic treatment from patients with septic arthritis. Arthritis Rheum 42(10):2198-2203. https://doi.org/10.1002/15290131(199910)42:10<2198::AID-ANR23>3.0.CO;2-N

25. Della Beffa C, Slansky E, Pommerenke C, Klawonn F, Li J, Dai L, Schumacher HR Jr, Pessler F (2013) The relative composition of the inflammatory infiltrate as an additional tool for synovial tissue classification. PLoS One 8(8):e72494. https://doi.org/10.1371/ journal.pone.0072494

26. Gerlag DM, Tak PP (2007) How useful are synovial biopsies for the diagnosis of rheumatic diseases? Nat Clin Pract Rheumatol 3(5): 248-249. https://doi.org/10.1038/ncprheum0485

27. Kroot EJ, Weel AE, Hazes JM, Zondervan PE, Heijboer MP, van Daele PL, Dolhain RJ (2006) Diagnostic value of blind synovial biopsy in clinical practice. Rheumatology (Oxford) 45(2):192-195. https://doi.org/10.1093/rheumatology/kei117

28. Krenn V, Morawietz L, Burmester GR, Kinne RW, Mueller-Ladner U, Muller B, Haupl T (2006) Synovitis score: discrimination between chronic low-grade and high-grade synovitis. Histopathology 49(4):358-364. https://doi.org/10.1111/j.1365-2559.2006.02508.x

29. Najm A, le Goff B, Venet G, Garraud T, Amiaud J, Biha N, Charrier C, Touchais S, Crenn V, Blanchard F, Krenn V (2019) IMSYC immunologic synovitis score: a new score for synovial membrane characterization in inflammatory and noninflammatory arthritis. Joint Bone Spine 86(1):77-81. https://doi. org/10.1016/j.jbspin.2018.04.004

30. Baeten D, Demetter P, Cuvelier C, Van Den Bosch F, Kruithof E, Van Damme N, Verbruggen G, Mielants H, Veys EM, De Keyser F (2000) Comparative study of the synovial histology in rheumatoid arthritis, spondyloarthropathy, and osteoarthritis: influence of disease duration and activity. Ann Rheum Dis 59(12):945-953. https://doi.org/10.1136/ard.59.12.945

31. Kraan MC, Haringman JJ, Post WJ, Versendaal J, Breedveld FC, Tak PP (1999) Immunohistological analysis of synovial tissue for differential diagnosis in early arthritis. Rheumatology (Oxford) 38(11):1074 1080. https://doi.org/10.1093/rheumatology/38.11.1074

32. Yeo L, Adlard N, Biehl M, Juarez M, Smallie T, Snow M, Buckley CD, Raza K, Filer A, Scheel-Toellner D (2016) Expression of chemokines CXCL4 and CXCL7 by synovial macrophages defines an early stage of rheumatoid arthritis. Ann Rheum Dis 75(4):763771. https://doi.org/10.1136/annrheumdis-2014-206921

33. Choi IY, Karpus ON, Turner JD, Hardie D, Marshall JL, de Hair MJH, Maijer KI, Tak PP, Raza K, Hamann J, Buckley CD, Gerlag 
DM, Filer A (2017) Stromal cell markers are differentially expressed in the synovial tissue of patients with early arthritis. PLoS One 12(8): e0182751. https://doi.org/10.1371/journal.pone.0182751

34. Bresnihan B, Pontifex E, Thurlings RM, Vinkenoog M, El-Gabalawy H, Fearon U, Fitzgerald O, Gerlag DM, Rooney T, van de Sande MG, Veale D, Vos K, Tak PP (2009) Synovial tissue sublining CD68 expression is a biomarker of therapeutic response in rheumatoid arthritis clinical trials: consistency across centers. J Rheumatol 36(8):1800 1802. https://doi.org/10.3899/jrheum.090348

35. Dennis G Jr, Holweg CT, Kummerfeld SK, Choy DF, Setiadi AF, Hackney JA, Haverty PM, Gilbert H, Lin WY, Diehl L, Fischer S, Song A, Musselman D, Klearman M, Gabay C, Kavanaugh A, Endres J, Fox DA, Martin F, Townsend MJ (2014) Synovial phenotypes in rheumatoid arthritis correlate with response to biologic therapeutics. Arthritis Res Ther 16(2):R90. https://doi.org/10.1186/ar4555

36. Pitzalis C, Kelly S, Humby F (2013) New learnings on the pathophysiology of RA from synovial biopsies. Curr Opin Rheumatol 25(3):334-344. https://doi.org/10.1097/BOR.0b013e32835fd8eb

37. Canete JD, Celis R, Moll C, Izquierdo E, Marsal S, Sanmarti R, Palacin A, Lora D, de la Cruz J, Pablos JL (2009) Clinical significance of synovial lymphoid neogenesis and its reversal after anti-tumour necrosis factor alpha therapy in rheumatoid arthritis. Ann Rheum Dis 68(5): 751-756. https://doi.org/10.1136/ard.2008.089284

38. Klimiuk PA, Sierakowski S, Latosiewicz R, Skowronski J, Cylwik JP, Cylwik B, Chwiecko J (2005) Histological patterns of synovitis and serum chemokines in patients with rheumatoid arthritis. J Rheumatol 32(9):1666-1672

39. van de Sande MG, Thurlings RM, Boumans MJ, Wijbrandts CA, Modesti MG, Gerlag DM, Tak PP (2011) Presence of lymphocyte aggregates in the synovium of patients with early arthritis in relationship to diagnosis and outcome: is it a constant feature over time? Ann Rheum Dis 70(4):700-703. https://doi.org/10.1136/ard.2010.139287

40. Thurlings RM, Wijbrandts CA, Mebius RE, Cantaert T, Dinant HJ, van der Pouw-Kraan TC, Verweij CL, Baeten D, Tak PP (2008) Synovial lymphoid neogenesis does not define a specific clinical rheumatoid arthritis phenotype. Arthritis Rheum 58(6):1582-1589. https://doi.org/10.1002/art.23505

41. Nerviani A, Di Cicco M, Mahto A, Lliso-Ribera G, Rivellese F, Thorborn G, Hands R, Bellan M, Mauro D, Boutet MA, Giorli G, Lewis M, Kelly S, Bombardieri M, Humby F, Pitzalis C (2020) A Pauci-immune synovial pathotype predicts inadequate response to TNFalpha-blockade in rheumatoid arthritis patients. Front Immunol 11:845. https://doi.org/10.3389/fimmu.2020.00845

42. Smeets TJ, Barg EC, Kraan MC, Smith MD, Breedveld FC, Tak PP (2003) Analysis of the cell infiltrate and expression of proinflammatory cytokines and matrix metalloproteinases in arthroscopic synovial biopsies: comparison with synovial samples from patients with end stage, destructive rheumatoid arthritis. Ann Rheum Dis 62(7):635-638. https://doi.org/10.1136/ard.62.7.635

43. van Oosterhout M, Bajema I, Levarht EW, Toes RE, Huizinga TW, van Laar JM (2008) Differences in synovial tissue infiltrates between anti-cyclic citrullinated peptide-positive rheumatoid arthritis and anti-cyclic citrullinated peptide-negative rheumatoid arthritis. Arthritis Rheum 58(1):53-60. https://doi.org/10.1002/art.23148

44. Orr C, Najm A, Biniecka M, McGarry T, Ng CT, Young F, Fearon U, Veale DJ (2017) Synovial immunophenotype and anticitrullinated peptide antibodies in rheumatoid arthritis patients: relationship to treatment response and radiologic prognosis. Arthritis Rheumatol 69(11):2114-2123. https://doi.org/10.1002/art.40218

45. van Baarsen LG, Wijbrandts CA, Timmer TC, van der Pouw Kraan TC, Tak PP, Verweij CL (2010) Synovial tissue heterogeneity in rheumatoid arthritis in relation to disease activity and biomarkers in peripheral blood. Arthritis Rheum 62(6):1602-1607. https://doi.org/10.1002/art.27415

46. Lliso-Ribera G, Humby F, Lewis M, Nerviani A, Mauro D, Rivellese F, Kelly S, Hands R, Bene F, Ramamoorthi N, Hackney JA, Cauli A, Choy EH, Filer A, Taylor PC, McInnes I,
Townsend MJ, Pitzalis C (2019) Synovial tissue signatures enhance clinical classification and prognostic/treatment response algorithms in early inflammatory arthritis and predict requirement for subsequent biological therapy: results from the pathobiology of early arthritis cohort (PEAC). Ann Rheum Dis 78(12):1642-1652. https://doi.org/10.1136/annrheumdis-2019-215751

47. Arnett FC, Edworthy SM, Bloch DA, McShane DJ, Fries JF, Cooper NS, Healey LA, Kaplan SR, Liang MH, Luthra HS et al (1988) The American Rheumatism Association 1987 revised criteria for the classification of rheumatoid arthritis. Arthritis Rheum 31(3):315-324. https://doi.org/10.1002/art.1780310302

48. Lindberg J, Wijbrandts CA, van Baarsen LG, Nader G, Klareskog L, Catrina A, Thurlings R, Vervoordeldonk M, Lundeberg J, Tak PP (2010) The gene expression profile in the synovium as a predictor of the clinical response to infliximab treatment in rheumatoid arthritis. PLoS One 5(6):e11310. https://doi.org/10.1371/journal.pone.0011310

49. Rivellese F, Humby F, Bugatti S, Fossati-Jimack L, Rizvi H, Lucchesi D, Lliso-Ribera G, Nerviani A, Hands RE, Giorli G, Frias B, Thorborn G, Jaworska E, John C, Goldmann K, Lewis MJ, Manzo A, Bombardieri M, Pitzalis C, Investigators P-RR (2020) B cell synovitis and clinical phenotypes in rheumatoid arthritis: relationship to disease stages and drug exposure. Arthritis Rheumatol 72(5):714-725. https://doi.org/10.1002/art.41184

50. Badot V, Galant C, Nzeusseu Toukap A, Theate I, Maudoux AL, Van den Eynde BJ, Durez P, Houssiau FA, Lauwerys BR (2009) Gene expression profiling in the synovium identifies a predictive signature of absence of response to adalimumab therapy in rheumatoid arthritis. Arthritis Res Ther 11(2):R57. https://doi.org/10.1186/ar2678

51. Zhang F, Wei K, Slowikowski K, Fonseka CY, Rao DA, Kelly S, Goodman SM, Tabechian D, Hughes LB, Salomon-Escoto K, GFM W, Jonsson AH, Rangel-Moreno J, Meednu N, Rozo C, Apruzzese W, Eisenhaure TM, Lieb DJ, Boyle DL, Mandelin AM, 2nd, Accelerating Medicines Partnership Rheumatoid A, Systemic Lupus Erythematosus C, Boyce BF, DiCarlo E, Gravallese EM, Gregersen PK, Moreland L, Firestein GS, Hacohen N, Nusbaum C, Lederer JA, Perlman H, Pitzalis C, Filer A, Holers VM, Bykerk VP, Donlin LT, Anolik JH, Brenner MB, Raychaudhuri S (2019) Defining inflammatory cell states in rheumatoid arthritis joint synovial tissues by integrating single-cell transcriptomics and mass cytometry. Nat Immunol 20(7):928-942. https://doi.org/10.1038/s41590-019-0378-1

52. Croft AP, Campos J, Jansen K, Turner JD, Marshall J, Attar M, Savary L, Wehmeyer C, Naylor AJ, Kemble S, Begum J, Durholz K, Perlman H, Barone F, McGettrick HM, Fearon DT, Wei K, Raychaudhuri S, Korsunsky I, Brenner MB, Coles M, Sansom SN, Filer A, Buckley CD (2019) Distinct fibroblast subsets drive inflammation and damage in arthritis. Nature 570(7760):246-251. https://doi.org/10.1038/s41586-019-1263-7

53. Alivernini S, MacDonald L, Elmesmari A, Finlay S, Tolusso B, Gigante MR, Petricca L, Di Mario C, Bui L, Perniola S, Attar M, Gessi M, Fedele AL, Chilaka S, Somma D, Sansom SN, Filer A, McSharry C, Millar NL, Kirschner K, Nerviani A, Lewis MJ, Pitzalis C, Clark AR, Ferraccioli G, Udalova I, Buckley CD, Gremese E, McInnes IB, Otto TD, Kurowska-Stolarska M (2020) Distinct synovial tissue macrophage subsets regulate inflammation and remission in rheumatoid arthritis. Nat Med. 26:1295-1306. https://doi.org/10.1038/s41591-020-0939-8

54. Wade SM, Canavan M, McGarry T, Low C, Wade SC, Mullan RH, Veale DJ, Fearon U (2019) Association of synovial tissue polyfunctional T-cells with DAPSA in psoriatic arthritis. Ann Rheum Dis 78(3):350-354. https://doi.org/10.1136/annrheumdis-2018-214138

Publisher's note Springer Nature remains neutral with regard to jurisdictional claims in published maps and institutional affiliations. 